\title{
Contradiction-oriented problem solving for innovations: five opportunities for China's companies
}

\author{
Runhua Tan
}

Correspondence: rhtan@hebut.edu.cn University Office, Hebei University of Technology, No.5340, Xiping Road Beichen District, 300401 Tianjin, China

\begin{abstract}
This paper focuses on the importance of contradictions and solving them for improving the innovative capabilities of engineers and their companies in China. The data are analyzed based on the collections from ten classes and ten projects of engineers from a national training program. A pattern that is an additional process model from main innovation processes is set up. Five innovative opportunities for companies are extracted. The study shows that to find and solve contradictions are the driving forces indeed for increasing both the engineers' and companies' innovative capabilities now in China.
\end{abstract}

Keywords: Contradiction solving; Training engineer; TRIZ; Innovative capability; Five opportunities

\section{Background}

"A nation's competitiveness depends on the capability of its industry to innovate and upgrade." (Porter 1990). Innovation for companies in China is also a fundamental choice for further development (Zhao and Zhang 2005; Zhang 2010). In 2008, the Chinese government made a training plan to transfer the knowledge of creativity and innovation to the companies nationwide in order to increase their innovative capabilities (Tan and Zhang 2014; Tan 2013). As a national center, we have carried out more than 40 classes as a part of the plan to train engineers from different kinds of companies of industries in China in the past few years.

One of objectives of the training program is to train many engineers for various industries and make them become innovative. We define that an innovative engineer is an industry-specific inventor, who makes inventions in order to improve product designs or processes in his/her workplaces (Tan 2013). Every engineer to join the classes must carry out a research project, in which he or she must be able to find and solve an inventive problem (Altshuller 1999; Savransky 1999) and to generate new ideas and push the ideas into inventions. The companies that the engineers come from may form development teams to transform the inventions into innovations after or during the process of training. In this way, the innovative capability for companies to join our classes is improved.

\section{Springer}

(c) 2015 Tan; licensee Springer. This is an Open Access article distributed under the terms of the Creative Commons Attribution License (http://creativecommons.org/licenses/by/4.0), which permits unrestricted use, distribution, and reproduction in any medium, provided the original work is properly credited. 
The key step for an engineer to follow our training class is to identify an inventive problem from his/her workplaces. An inventive problem is a typical problem to be solved using TRIZ (Altshuller 1999), the theory of inventive problem solving. TRIZ was developed by Genrich Altshuller (1926 to 1998) and his colleagues, who studied many patents and drew out some regularities and patterns that governed the processes of solving problems, creating new ideas and innovations. Savransky (1999) defines the inventive problem as "a problem which includes a contradiction and/or for which a path to a solution is unknown." There are several kinds of inventive problems (Karen 2011) and contradiction is a typical one.

The engineers who join our classes are from different companies in one region or various workplaces from one company. Many engineers identify contradictions as the inventive problems for their research projects. How to find and solve contradictions from various situations for them and whether the contradictions are important for innovations in companies in China should be studied.

This paper first makes a literature review, distinguishes two kinds of contradictions, and raises a few questions. Then project data from ten training classes and ten project cases are analyzed for finding some clues. The process to find and solve contradictions for engineers is studied in order to look at the possible pattern. At the end of the study, some conclusions are summarized.

\section{Literature review}

The knowledge system for training engineers, which is transferred to the companies of China, is a system with four knowledge levels and application cases (Tan 2013). TRIZ is in the core place of the system. Other knowledge is innovative processes, creative techniques, computer-aided innovations (Leon and Cho 2009), and applied cases. Though there are several methods in TRIZ, the review (Imoh 2011) shows that contradiction solving is a more applicable one in practice.

There are three kinds of contradictions in TRIZ (Altshuller 1999; Rousselot et al. 2012), administrative, technical, and physical contradiction. An administrative contradiction describes a desire to improve a characteristic of a system without having an emerging direction of resolution. A technical contradiction describes the state of a system where there is an action having a useful effect but causing simultaneously an undesirable effect. The physical contradiction addresses the part of the technical contradiction centered on that parameter that must have at the same time two opposite values.

A method for contradiction solving in TRIZ means to solve a technical or physical contradiction using the concepts, tools, and techniques of TRIZ to find its solutions. The method for technical contradiction solving is a 12-step sequential algorithm in which the 39 engineering parameters, 40 inventive principles, contradiction matrix, and many cases are applied to find the solutions of a technical contradiction (Savransky 2000; Tan 2002). The method for physical contradiction solving is also a process using four separation principles and cases (Savransky 2000; Tan 2002).

A typical project for an engineer in our class is to identify a technical, physical, or both contradictions as inventive problems in his or her workplace and solve them to form inventions. We define the technical and physical contradictions as operating 
contradictions because the engineers can operate and find solutions for them to form inventions in workplaces in this study. We focus on the narrow area, the study of the method for operating contradiction solving in TRIZ, and make the following literature review in this area.

\section{Development of the method}

The existing method for contradiction solving in TRIZ should be improved in order to make it adapt to more various applications. Rousselot et al. (2012) propose a formal definition of the contradictions in accordance of TRIZ for inventive design. Baldussu et al. (2011) develop an algorithm to guide the problem solver to choose the most important one in the contradiction network of a design. Yeh et al. (2011) apply QFD to identify contradictions. Herstatt and Kalogerakis (2005) apply the contradictions of TRIZ to retrieve analogies for breakthrough innovations. Mann et al. (2003) update the TRIZ contradiction matrix in which the parameter number is 48 . Cavallucci et al. (2010) present a formalization of the initial situation analysis of design in order to gather contradictions to improve the first step of applying TRIZ.

The researchers have studied the chain from the initial situation to the solutions for contradictions of TRIZ. But for the engineer who is working in a company, to identify a potential initial situation is the most important step for invention. How to identify the situation from fuzzy phenomenon remains an unstudied topic.

\section{Applications of the method}

There are also many studies to apply the method of operating contradictions of TRIZ to solve practical problems. Srinivasan and Krasla (2006) show two cases to apply the matrix and inventive principles of TRIZ to solve technical contradictions in the improvement of chemical processes. Cempel (2013) presents an integration of the matrix and principles with system condition monitoring to solve several technical contradictions. Juppa et al. (2013) find the application of solving technical contradictions in a service diagnostic system for a synchronous belt transmission. Li (2010) also uses the matrix and inventive principles to solve technical contradictions of an automated assembly line. Hsieh and Chen (2010) identify the technical contradictions in a friction stir-welding process and solve them by using the method of TRIZ. Kiatake and Petreche (2012) make application of technical contradiction solving of TRIZ in architectural design. Tan et al. (2009) extend the method of contradiction solving to the conceptual design to form a new conceptual design model.

The authors of the above studies are all TRIZ experts or have learned TRIZ for years. They may use the methods of TRIZ smoothly. But for engineers, there is difficulty in acquisition and application of TRIZ knowledge (Imoh et al. 2011). Our experiences (Tan and Zhang 2014) show that more than half of the engineers joining our classes may apply one method of TRIZ to solve a real engineering problem after a training process of at least in 6 months.

\section{Administrative contradictions}

There are one or two papers to deal with the relationships between the administrative and operating contradictions. Petrov (2004) defines that an administrative contradiction 
is the contradiction between the expressed need and ability to satisfy that need. The features of this kind are that they are sufficiently easy to determine and often found by administrators or customers. The remarkable point of view of this paper is that one administrative contradiction is transferred to operating contradictions to be solved. Houssin and Coulibaly (2011) identify organizational contradictions, which are situations in which the improvement of a procedure increases workload or system complexity. They also find that the kind of contradiction could fall again on an operating contradiction to be solved. The definition of the administrative and organization contradiction in both studies looks the same.

The researches show the truth that the administrative contradictions may be transformed to operating contradictions to be solved. But something is in a fuzzy state, such as whose job it is to find administrative contradictions and make the transformation in a company and whether or not an engineer in our classes should pay more attention to them.

\section{Training of TRIZ}

There are several studies related to the training of TRIZ. Nakagawa (2011) trains engineers in Japan in a 2- or 3-day TRIZ/Unified Structured Inventive Thinking (USIT) in the form of seminars and also undergraduate students in a university. The training seminars show that almost all the joining engineers can understand how they actually applied USIT to the problem solving, but their capabilities of applying TRIZ/USIT to other problems are often not enough unless they try to study more about TRIZ/USIT for themselves and to keep applying TRIZ/USIT to other real problems. Belski (2011) finds that the engineering students improved their problem-solving abilities after taking part in the TRIZ training. Hernandez et al. (2013) concludes that TRIZ is an effective method for ideation and can lead to broader sets of solutions than when engineering students address the design task without any formal ideation method. Birdi et al. (2012) indicates that participation in TRIZ training for engineers led to short-term improvements in both the creative problem-solving skills and motivation, and these are associated with longer term improvements in their idea suggestion in the workplace. Lee (2013) summarizes that there are 4R's for effective strategy of TRIZ in a company in Korea in which training is the basic activity.

The studies above mostly relate to the training for students in universities. For training engineers, there are only the introductions in the macro level. Detailed study for the process and how to improve it in the micro level are to be studied.

All in all, there are many studies for the development and applications of the contradiction-solving method in TRIZ. Some research results are positive and extend the boundary of TRIZ. But there are also some problems that need to be studied further. We post the following three questions to study in the following of this paper.

Q1: Are there many operating contradictions in innovation processes in the companies in China?

Q2: How to find operating contradictions for innovative engineers, and is there any pattern for identifying and solving them in the companies in China?

Q3: Could some opportunities for innovations in companies be identified from the engineers' projects in our classes and serve to improve the training program in China? 


\section{Methods}

Project study of innovative engineers

Project data analysis

An entire innovation process in a manufacturing company is typically divided into three stages: fuzzy front end (FFE), new product development (NPD), and commercialization (Koen et al. 2002). The outputs of FFE are the ideas evaluated and are the input of NPD. In the NPD stage, the ideas from FFE are transformed into products. There are two sub-stages in NPD, design and manufacturing. In the design stage, there are three main sub-stages, namely conceptual design, embodiment design, and detailed design (Pahl and Beitz 1996). In the manufacturing stage, the first step is to design the process and then the actual manufacturing. The commercialization is the last stage, in which the products are put into markets. Based on this process, we have developed an interactive training model for innovative engineers in China (Tan 2013) as shown in Figure 1.

According to this model, the training process is seven steps which are selecting companies, selecting engineers, training stage-1, finding problems, training stage- 2 , finding solutions, and summing up. A full process for a class lasts 6 to 15 months accordingly. The training outputs are the inventions of different kinds and some innovative engineers. After training or in the training process, the relevant teams in the company that the engineers come from will make further development of the innovations.

There may be only one or many companies joining one class at the same time. For example, GD and TG are two class cases, which are organized by the Guangdong and Henan province, respectively. GD was carried out from August of 2010 to March of 2011, and 75 engineers were selected for training from 19 companies, including BYD, BROAD-OCEAN, and GAC. Fifty-two passed the final examination. TG was the first class held in Henan province from July of 2010 to February of 2011, and all the engineers were from one company, in which 20 engineers passed the final examination who are certificated innovative engineers in China.

Step 4 is finding, which is the key step for an engineer to follow the class. He or she must find an inventive problem in his or her workplace in this step. The basic concepts, processes, and cases of TRIZ from training are the new knowledge for the engineers. They should apply the knowledge to look at their workplaces, design, manufacturing, management, users, national, and international markets again. They may make many discussions with the other engineers, marketers, and managers many times. At last, he or she identifies an inventive problem to be solved for following in our class. In some

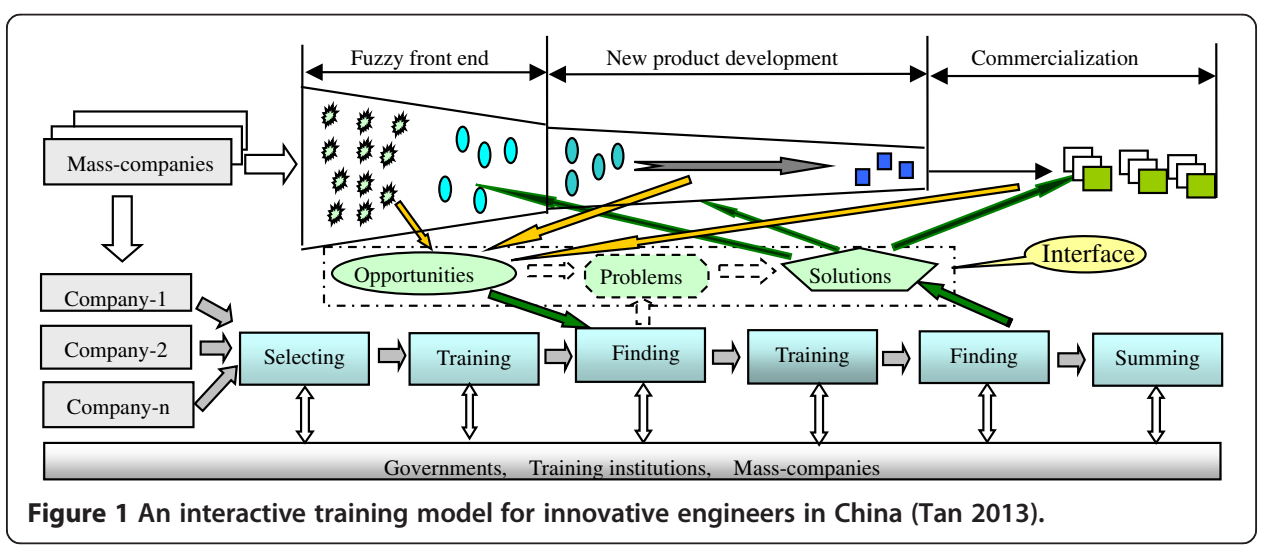


companies, the managers in a certain level do spend a lot of time to assist the engineers to find the problems. Step 4 is the process for an engineer to set up a research project.

If the project for an engineer in our class is to solve an operating contradiction, the method of contradiction solving in TRIZ is applied to find solutions. Numbers for engineers who select the operating contradictions as the research projects should be studied.

We collect all the project documents from the ten classes which were organized in different regions of China from 2009 to 2012 and analyze the data. Figure 2 is the statistical results. The $x$-coordinate is the names of the classes which are abbreviations of full names, such as QH means Qinghai class that is carried out in Qinghai province. The $y$-coordinate is the number of the total projects in the class and that related to the solving contradictions. As a whole, there are 244 projects in the ten classes and 164 of them are related to solving contradictions, which is $67.2 \%$ in the total projects.

Why is contradiction solving frequently selected as a research projects for the engineers who join our training classes from companies of different regions? We have made many face-to-face discussions with the engineers and some managers and visited many workplaces in different companies. Three factors have been identified as follows:

Factor 1: Many contradictions do exist. For the survival of companies, more and more changes must be made in order to become adaptive to the situation of market competitions. The changes in product designs or manufacturing processes result in many contradictions which the engineers and managers always face in China's companies.

Factor 2: A contradiction solving always results in an incremental innovation. Much payment may not be needed for this kind of innovation. So, it may be implemented by the engineers who join our classes and the related teams in a short time and in a relatively lower investment.

Factor 3: The concepts about contradictions in TRIZ are relatively easier to be understood for the engineers in China. And there is a systematic process and knowledge to solve contradictions in TRIZ. Many cases in different domains are analogies for engineers to solve their own contradictions (Tan, 2007).

Imoh et al. (2011) show that "All of the respondents indicated that they had applied the 40 inventive principles, which also appears to be a tool used very often (with 30 of the 40 respondents indicating that they used the tool often or always)." The inventive principles as a tool are used to solve operating contradictions in TRIZ. In our cases, there are $67.2 \%$ of total projects in which the inventive principles are related. The

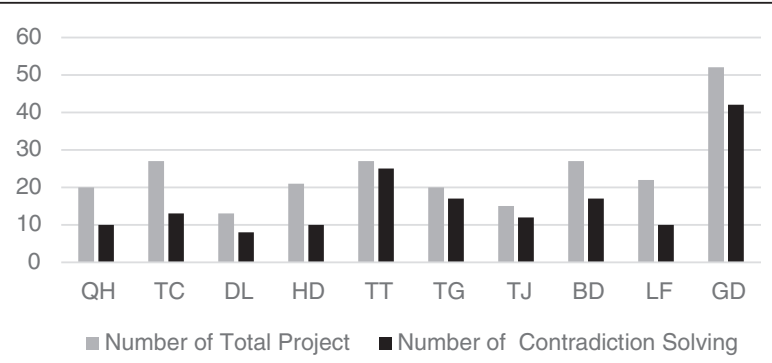

Figure 2 Project numbers for ten classes. 
frequency for dealing with operating contradictions in both the companies reviewed (Imoh et al. 2011) and the companies in China is similar.

\section{Project case study}

More engineers in our classes select operating contradictions and solve them to produce inventions as the sources of following innovations. The engineers for a region in one class come from different companies with various backgrounds of domain knowledge. The knowledge to be transferred to the engineers in the training process is mainly about how to solve operating contradictions in TRIZ. Identifying one or more operating contradictions from a workplace for an engineer is mysterious for our training team at first.

Every engineer to join our training classes does have a document to record all the information from the situation of the company to the solutions of his or her project. As a case study, we will analyze ten project documents of the engineers, who are from different companies of Hebei, Guandong, and Tianjin, and try to find a general domainindependent process. Table 1 shows the ten projects.

In Table 1, the location of the company is the city in which the engineer works. The main products are the outputs of the company. The project's name is the topic that the engineer selects in the training process. The original situation is a description about the problematic information that the company or the engineer faces at the beginning. The domain problem is abstraction from the original situation. TRIZ problem is a transformation of domain problem into the problem in TRIZ. Solutions are the results of solving domain and TRIZ problems.

There are three key steps for an engineer to carry out a project, describing the original situation, identifying the domain problem, finding TRIZ problems, and solving them in a company level. The original situation for a company includes two aspects, facts and dilemma. Facts are something that have really occurred or are actually the cases. Dilemma is a situation in which the engineer has to make a difficult choice. In project No.1, the fact is that a bridge girder erection machine for small-curve roads is needed in the new market because of the development of high-speed railway in some regions in China. The dilemma is that the existing machines could not be used and the new machines developed recently are weighty and with high cost.

The second step for engineers is to identify the domain problem, which is abstracted from the original situation. There may be several domain problems from the situation, which are related to the dilemma. The engineer must select one as the problem he/she should solve for the project. The problem selected is an administrative contradiction. For example, that the domain problem in project No.1 is "How to decrease the weight of the structures and costs of the machines and keep the needed functions and performances?" is an administrative contradiction.

The third step is to identify and solve the TRIZ problems. The problems in this step are operating contradictions. There are one or more TRIZ problems from one administrative contradiction, which depends on the domain problem selected. In No.5 and No.10, examples are there are three and eight technical contradictions to be solved, respectively. The method of contradiction solving of TRIZ is applied, including some cases as analogies. Some better solutions could be obtained after the engineer's efforts, 
Table 110 projects for innovative engineers

\begin{tabular}{|c|c|c|c|c|c|c|c|}
\hline Number & $\begin{array}{l}\text { Location of } \\
\text { company }\end{array}$ & $\begin{array}{l}\text { Main } \\
\text { products }\end{array}$ & Project name & Original situation & Domain Problem & $\begin{array}{l}\text { TRIZ } \\
\text { problem }\end{array}$ & Solutions \\
\hline 1 & Qinhuangdao & $\begin{array}{l}\text { Construction } \\
\text { machineries }\end{array}$ & $\begin{array}{l}\text { A new bridge } \\
\text { girder erection } \\
\text { machine for small } \\
\text { curves }\end{array}$ & $\begin{array}{l}\text { The development of high-speed railway in china } \\
\text { needs a bridge girder erection machine for small- } \\
\text { curve roads. But structures for the machines used } \\
\text { now are weighty and costs more for constructing } \\
\text { the bridges over this kind of roads }\end{array}$ & $\begin{array}{l}\text { How to decrease the weight of the structures } \\
\text { and costs of the machines and keep the } \\
\text { functions and performances }\end{array}$ & $\begin{array}{l}\text { A technical } \\
\text { contradiction }\end{array}$ & Two patents \\
\hline 2 & Shijiazhuang & $\begin{array}{l}\text { Valves with } \\
\text { big } \\
\text { diameters }\end{array}$ & $\begin{array}{l}\text { A new class valve } \\
\text { for energy saving }\end{array}$ & $\begin{array}{l}\text { In some iron and steel plants stiffened plates are } \\
\text { added to increase the strength of a class valve for its } \\
\text { application in a higher pressure situation. Sometimes } \\
\text { a butterfly valve is needed. This results in some } \\
\text { harmful effects, such as high cost, complex process, } \\
\text { and increased weight }\end{array}$ & $\begin{array}{l}\text { How to design a class valve which has the } \\
\text { ability to bear high pressures in double } \\
\text { directions? At the same time, the butterfly } \\
\text { valve should not be needed for the new } \\
\text { design }\end{array}$ & $\begin{array}{l}\text { A technical } \\
\text { contradiction }\end{array}$ & $\begin{array}{l}\text { Two new } \\
\text { products for the } \\
\text { specific } \\
\text { application }\end{array}$ \\
\hline 3 & Tianjin & $\begin{array}{l}\text { New } \\
\text { materials for } \\
\text { batteries }\end{array}$ & $\begin{array}{l}\text { A new process for } \\
\text { producing a new } \\
\text { material }\end{array}$ & $\begin{array}{l}\text { A material with high performance used in batteries is } \\
\text { produced in one company in Japan and two in } \\
\text { Korea in the world now. The company has high } \\
\text { pressure to improve its production processes in order } \\
\text { to produce the material of the kind with acceptable } \\
\text { performances }\end{array}$ & $\begin{array}{l}\text { How to reduce the amount of oxygen gas, or } \\
\text { even better, in atmospheric conditions, to } \\
\text { achieve a synthesis reaction }\end{array}$ & $\begin{array}{l}\text { A physical } \\
\text { contradiction }\end{array}$ & $\begin{array}{l}\text { A new process to } \\
\text { produce the new } \\
\text { material with high } \\
\text { performance }\end{array}$ \\
\hline 4 & Xinhe & $\begin{array}{l}\text { Drilling } \\
\text { machines }\end{array}$ & $\begin{array}{l}\text { Improvement of } \\
\text { the structure for a } \\
\text { spiral drilling rod }\end{array}$ & $\begin{array}{l}\text { A structure attached to the spiral drilling rod for a } \\
\text { kind of drilling machine could not fulfill the function } \\
\text { of cleaning soil well. This results in low efficiency for } \\
\text { drilling and safety problems }\end{array}$ & $\begin{array}{l}\text { How to make redesign for the structure that } \\
\text { cleans the soil well }\end{array}$ & $\begin{array}{l}\text { A technical } \\
\text { contradiction }\end{array}$ & A patent \\
\hline 5 & Shenzhen & Batteries & $\begin{array}{l}\text { Improvement of } \\
\text { the corrosion } \\
\text { resistance for a } \\
\text { battery frame }\end{array}$ & $\begin{array}{l}\text { The improvement of the corrosion resistance for a } \\
\text { battery frame is the market need of the company. } \\
\text { But the improvement results in increasing the cost. } \\
\text { This is not allowed in this company }\end{array}$ & $\begin{array}{l}\text { How to make an improvement of the } \\
\text { corrosion resistance with low cost }\end{array}$ & $\begin{array}{l}\text { Three } \\
\text { technical } \\
\text { contradictions }\end{array}$ & Two patents \\
\hline 6 & Shunde & $\begin{array}{l}\text { Water } \\
\text { heaters }\end{array}$ & $\begin{array}{l}\text { Improvement of } \\
\text { welding process } \\
\text { for a kind of heat } \\
\text { exchanger }\end{array}$ & $\begin{array}{l}\text { A kind of heat exchanger is made of aluminum. The } \\
\text { quality of the component using the welding process } \\
\text { now is good. But the process is too complex to be } \\
\text { simplified in order to increase the manufacturing } \\
\text { efficiency }\end{array}$ & $\begin{array}{l}\text { How to simplify the welding process and keep } \\
\text { the quality at the same time }\end{array}$ & $\begin{array}{l}\text { A technical } \\
\text { contradiction }\end{array}$ & $\begin{array}{l}\text { The improved } \\
\text { welding process }\end{array}$ \\
\hline
\end{tabular}


Table 110 projects for innovative engineers (Continued)

\begin{tabular}{|c|c|c|c|c|c|c|c|}
\hline 7 & Guangzhou & $\begin{array}{l}\text { Engineering } \\
\text { plastics }\end{array}$ & $\begin{array}{l}\text { A new process to } \\
\text { eliminate the } \\
\text { impurities in an } \\
\text { engineering } \\
\text { plastic }\end{array}$ & $\begin{array}{l}\text { The process being used needs a lot of water to } \\
\text { eliminate the impurities. The water needs to be } \\
\text { heated and energy is consumed. The treatment of } \\
\text { used water also needs energy consumption }\end{array}$ & $\begin{array}{l}\text { How to decrease the amount of water used in } \\
\text { this process and keep the quality }\end{array}$ & $\begin{array}{l}\text { Two technical } \\
\text { contradictions }\end{array}$ & Three patents \\
\hline 8 & Shenzhen & Watch & $\begin{array}{l}\text { A new process to } \\
\text { remove burrs in } \\
\text { elements }\end{array}$ & $\begin{array}{l}\text { The method to remove burrs in elements of a watch } \\
\text { is artificial process under microscopes with low } \\
\text { efficiency, damaging the elements easily; unstable } \\
\text { quality }\end{array}$ & $\begin{array}{l}\text { How to design a new process to increase } \\
\text { efficiency, lowering damage and keeping high } \\
\text { quality }\end{array}$ & $\begin{array}{l}\text { A technical } \\
\text { contradiction }\end{array}$ & $\begin{array}{l}\text { New process, } \\
\text { which is applied } \\
\text { and has good } \\
\text { results }\end{array}$ \\
\hline 9 & Shijiazhuang & $\begin{array}{l}\text { New product } \\
\text { development }\end{array}$ & $\begin{array}{l}\text { Improvement of } \\
\text { assorting } \\
\text { machine for } \\
\text { specific bottles }\end{array}$ & $\begin{array}{l}\text { A sorting machine for bottles is being developed. } \\
\text { One function of the machine is to measure the } \\
\text { inside and outside diameters of the bottles during } \\
\text { transmitting them. The current design shows low } \\
\text { measuring efficiency }\end{array}$ & $\begin{array}{l}\text { How to overcome the contradiction between } \\
\text { measuring efficiency and complexity }\end{array}$ & $\begin{array}{l}\text { Two technical } \\
\text { contradictions }\end{array}$ & $\begin{array}{l}\text { A new product, } \\
\text { which has been } \\
\text { developed and } \\
\text { sold }\end{array}$ \\
\hline 10 & Tianjin & $\begin{array}{l}\text { Hydraulic } \\
\text { machines }\end{array}$ & $\begin{array}{l}\text { The heat } \\
\text { radiation for } \\
\text { electric element } \\
\text { in a control } \\
\text { system }\end{array}$ & $\begin{array}{l}\text { The company is developing a big actuator and its } \\
\text { control system. The electric element in the system } \\
\text { will produce heat during the work. The working } \\
\text { temperature for the element should not be higher } \\
\text { than a certain numerical value }\end{array}$ & $\begin{array}{l}\text { How to make a redesign for the specific } \\
\text { electric element to reduce its working } \\
\text { temperature }\end{array}$ & $\begin{array}{l}\text { Eight } \\
\text { technical } \\
\text { contradictions }\end{array}$ & $\begin{array}{l}\text { New concept has } \\
\text { been developed } \\
\text { for the heat } \\
\text { radiation system }\end{array}$ \\
\hline
\end{tabular}


which are inventions. Some inventions have transformed to new technologies, processes, or products at the end of the training classes.

The domain problem or an administrative contradiction is the result of analyzing the original situation and making abstraction. This is also a process in which the managing team of a company and the engineer of our class may join together. In fact, the domain problems in some companies are identified by the managing team and technical team together because the solutions of the problems are the directions of the next innovations for the companies. But the TRIZ problems are identified by the engineers who join our classes. The process from domain problems to TRIZ problems is special, in which the knowledge system transferred by training should be applied. Figure 3 shows the three key steps.

In Figure 3, the domain problem or the administrative contradiction is an interface between the original situation that the company faces and the TRIZ problems the engineer faces. The knowledge system transferred to the engineers by training is just for them to solve TRIZ problems or operating contradictions. The solutions will help the company to overcome the dilemma that the company faces.

Identification of an operating contradiction is called problem formulation in some studies (Albers et al. 2011; Russo and Birolini 2011), in which the micro level of identification of a contradiction is presented in detail. Petrov (2004) gives the view that administrative contradictions are easy to be identified and an administrative and its operating contradictions form a chain. From many discussions with engineers as their tutors and visiting workplaces in companies, we find that the most administrative contradictions are not in the superficial state but implicated. Based on the data of analyzing the project cases, we also find that the transformation from an administrative contradiction to operating contradictions is direct only in a small number, but for most, it is not. The general pattern for contradiction solving in the company level needs to be studied further.

\section{Pattern for identifying and solving contradictions Identification of an original situation}

Trying to change an original situation is the starting point of the project for an engineer in our classes. What is the original situation to be changed and how is the situation identified by the engineer? This should be answered.

A typical innovation process includes a few stages: fuzzy front end, conceptual design, embodiment design and detailed design, process design, and manufacturing. We define that every stage or sub-stage is a phase. Studies of the projects in Table 1 and discussions with the engineers show that problems may exist in every phase, and the problem

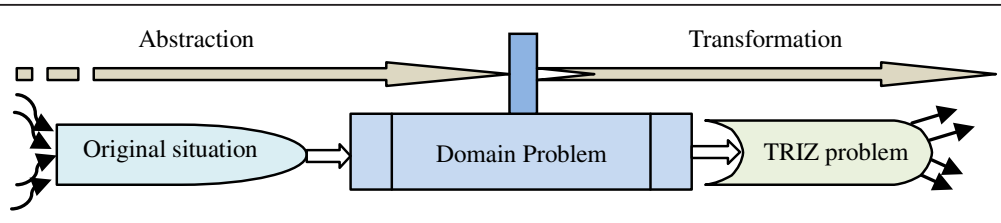

Figure 3 Simple process for state change of problems. 
identified in a phase may be solved in another phase. Different problem flows exist among phases, as shown in Figure 4.

A problem is defined as a difference between actual conditions and those that are required or desired. Managers, salesmen, engineers, or other related people in different workplaces may find problems if they study each phase of the innovation process. We divide all these problems into three types: forward flow, backward flow, and self-solving flow. A forward flow problem is one that should be solved in the next or a following phase. For example, it is that kind of problem in which the problem identified in embodiment design should be solved in process design. A backward flow problem should be solved in the upstream phases. For example, that the problem found in the process design should be solved in conceptual design is that kind of problem. That a problem in a phase must be solved in this phase is a self-solving problem. That the problem found in the conceptual design phase should be solved in this phase is a case.

From project No.1 to 5 in Table 1, the problems are originally identified in the phase of commercialization as backward flow problems and fed back to conceptual design for No.1 and 2, process design for No.3, embodiment design for No.4, and process design for No.5. The problems in No.6 and 7 are originally found in the manufacturing process and solved in this process. The problem in No.8 is originally identified in the manufacturing process and solved in process design. In No. 9, the problem is in the manufacturing process and is solved in conceptual design. The problem in No.10 is originally in the manufacturing process but is solved in conceptual design.

If a problem is determined to be solved in the workplace where the engineer works, that is named an original problem in this study. The typical original problem is a dilemma for changing a situation. When an engineer faces the problem, he or she could not find its solutions easily because of its fuzzy characteristics. He or she must make detailed analysis in order to find the depth or implied problem. As a result, the engineers call the original problems as original situations.

The original problem or situation is first abstracted to form an administrative contradiction, which is a domain problem. Then, it is transformed to one or more operating contradictions or TRIZ problems. The knowledge of TRIZ is used to solve the TRIZ problems. Last, the original problem that the engineer is facing is solved as the solutions of the TRIZ problems in a company.

\section{An interface to transfer the knowledge to companies}

An original problem in a company may come from every phase of an innovation process. All the original problems in a company form a group or a level. We define this

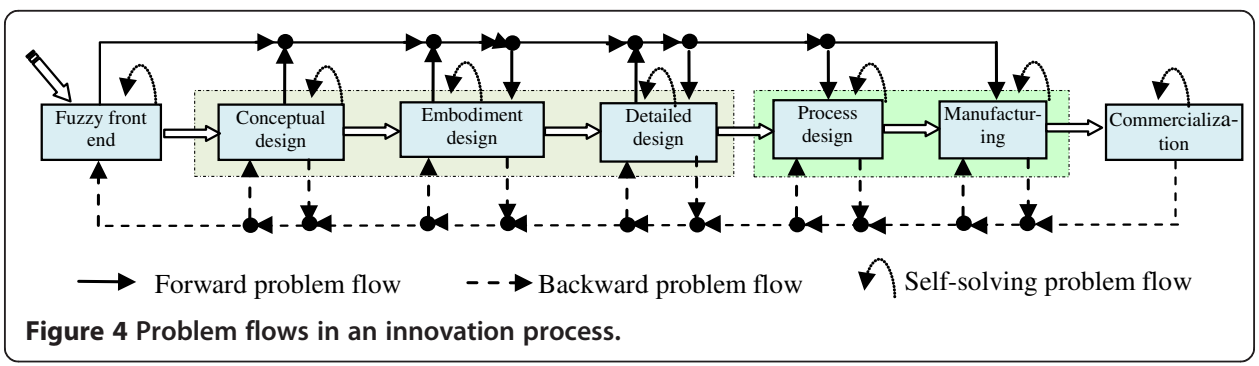


level as a managing problem level. Under this level is an operating level including all the operating contradictions, which are technical or physical contradictions. The two levels form an interface between an innovation process and the knowledge system to be transferred as shown in Figure 5 .

The knowledge system with TRIZ as the core is contributed to solve contradictions. But one of the challenges associated with TRIZ is "difficulty in acquisition and application of TRIZ knowledge" (Imoh, et al. 2011). The interface is a middle stage or a bridge in terms of transferring the knowledge to the engineers in companies and reducing the difficulty for them to apply the contradiction-solving method of TRIZ in practice.

The interface is as a kind of bridge for engineers in the following aspects:

(1) An original problem may be transformed to one or more operating contradictions by the information exchange between the managing problem level and the operating contradiction level.

(2)An operating contradiction which is formed from every phases can be solved using the contradiction-solving method of TRIZ.

(3) To solve a contradiction is a process in which some cases from various domains with similar problems in TRIZ should be applied. The application of cases from different domains as analogies will accelerate the problem-solving process and also improve the quality of solutions.

\section{An additional process for innovation}

An original problem may occur in every phase in an innovation process, which forms an obstacle for the process. If the obstacle is not eliminated, the innovation process could not move forward. In this situation, an additional process is needed outside the main innovation process, by which the obstacle is eliminated. From the ten projects, we know that the root causes of the original problem are one or several operating contradictions. We define that the additional process is a model to identify and solve contradictions using the method of TRIZ as shown in Figure 6.

The processes are divided into 6 steps. The outputs of the process are the evaluated solutions of the original problem which will be fed back to the phase where the

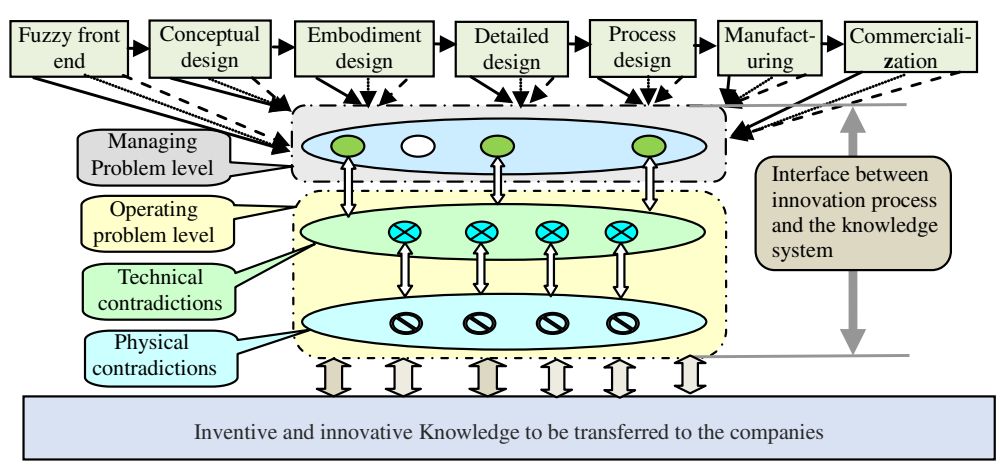

Figure 5 Interface between an innovation process and the inventive and innovative knowledge system. 


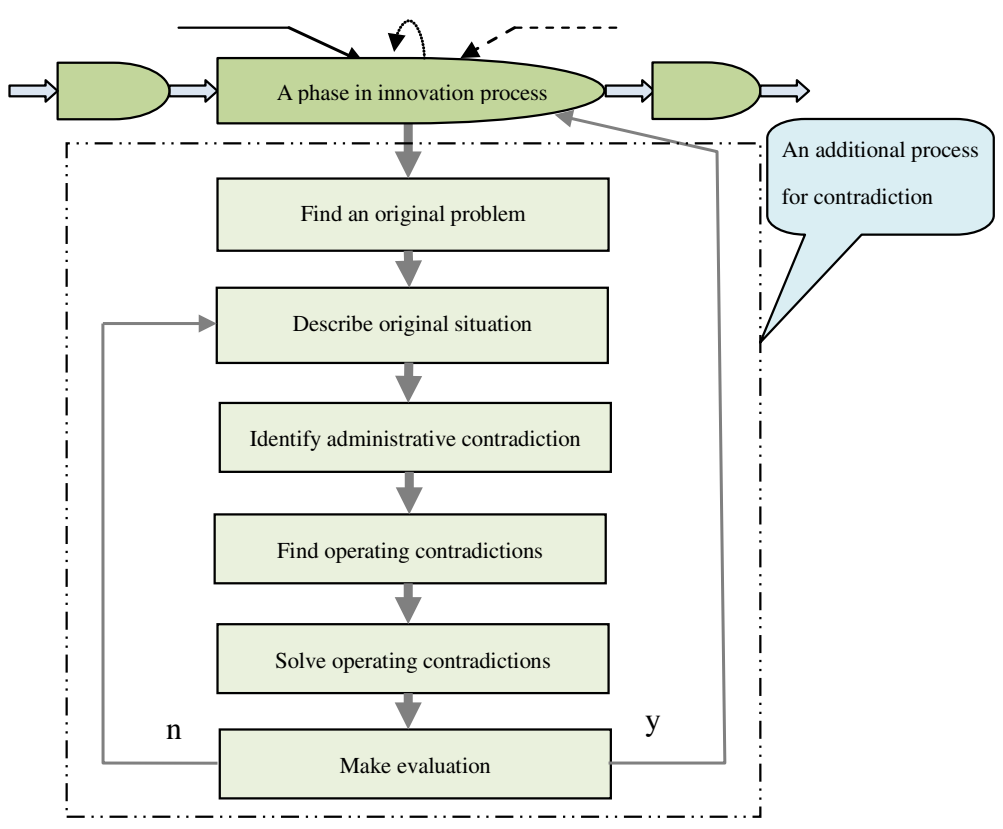

Figure 6 Process model for identifying and solving contradictions in a phase.

problem is identified. After the solutions are applied, the obstacle is eliminated and the innovative process goes on. The six steps are as follows:

Step 1: Find an original problem. The problem may come from any other phases or the phase in which the engineer works.

Step 2: Describe the original situation. This is the description of the original problem, in which the facts and dilemma are included. Facts are a real and simple description of the phenomenon. Dilemma is a situation in which the engineer has to make a difficult choice.

Step 3: Identify the administrative contradiction. After an abstraction process, the dilemma is changed to an administrative contradiction, or a domain problem, which is presented by "How to ...?" But the solutions of the administrative contradiction do not exist clearly at this stage.

Step 4: Find operating contradictions. A transformation process is needed to find the operating contradictions as root causes of the administrative contradiction. The process may be direct or complex that depends on the different situations. The operating contradictions found are TRIZ problem, or inventive problems.

Step 5: Solve operating contradictions. The method of contradiction solving in TRIZ is applied to the operating contradictions. Some solutions should be obtained.

Step 6: Make an evaluation. There are a few solutions from the operating contradictions. Make an evaluation to select one or two as the inventions for the following innovation. If the evaluation results show that the selection is accepted, the process is returned to the main innovation process. If not, the process is returned to step 2 .

The six-step process model is domain independent and forms a pattern. The engineers in the future classes may follow the process or pattern and apply the inventive and innovative knowledge to find and solve inventive problems and form inventions. 
Opportunities of innovations for companies

Five innovative opportunities

The ten projects in Table 1 show that solving operating contradictions results in the elimination of technical obstacles in the innovation process and makes the innovation possible. The operating contradictions are in the level that the engineers may directly apply the knowledge of TRIZ into practice to solve them. The contradictions are from an administrative contradiction and an original situation in a company. The solutions of the contradictions meet the new market or technology needs and assist to improve the competitive capability of the company.

In management literatures, there are several studies to deal with contradictions. Cousins et al. (2007) report that remoteness-closeness, cultural uniformity-cultural diversity, and rationality-emotionality are contradictions in hybrid teams and should be managed for trade-offs over time. Harnesk and Abrahamsson (2007) show that the leaders in companies should make balances between contradictions in which collectivism versus individualism, manipulation versus empowerment, and standardization versus innovative learning are cases. Schultz and Stabell (2004) use the contradiction of managing tacit knowledge as an analytical device to explore four discourses. Smith and Tushman (2005) argue that the companies should manage strategic contradictions between exploring and exploiting. In Toyota, contradictions are created and solved to come up with fresh ideas as a kind of culture (Takeuchi et al. 2008).

The contradictions in these studies are in the levels of strategy, management, or culture. But, there is almost no study about the relationship between the contradiction solving of TRIZ and the contradictions in the strategy level in both management and engineering literatures. We find the fact that the solutions of the operating contradictions in the ten engineers' projects of Table 1 are patents or new technologies, which do assist the implement of the innovative strategies of the related companies. The relationships between the contradictions in strategy level and the operating contradiction level in a company do exist, at least in some situations.

From the analysis of the ten projects in Table 1, we find one clue of the relationships that there are five opportunities for the innovative driven development of companies as the results of solving operating contradictions.

Opportunity 1: development of a new product for the niche market appeared just now No.1 in Table 1 is a case of this kind. High-speed railway with a small curve is new situation in the history of railway construction in China. A new machine for constructing the bridge over the road with a small curve is a new niche market. The company that the engineer works for faces a strategic contradiction between exploring and exploiting technologies (Smith and Tushman 2005). After abstraction and transformation, the contradiction is changed to an operating contradiction. The solutions of the operating contradiction results in the development of a new product which is suitable for the niche market appeared just in China.

New niche market is a chance for a company. The development of new products for the market may be a difficult process. To identify and solve operating contradictions implied are an opportunity of innovation in the company. 
Opportunity 2: development of a new product for catching up with the performance benchmarking No.3 is a case of this kind. The company in Tianjin faces the challenge of developing a new material with similar performances to the benchmarking products of other countries. The production process in this company must be changed. The strategic contradiction is the balance between exploring and exploiting process technologies (Smith and Tushman 2005). The engineer applies TRIZ to find that the root cause or a technical obstacle is an operating contradiction. After solving the contradiction, a new production process is built and the performance of the material is in high level.

The case shows that eliminating a technical obstacle or an operating contradiction is a key step for catching up with the performance of a benchmarking product. Sometimes operating contradiction solving is an opportunity for benchmarking in companies.

Opportunity 3: development of a new product from elimination of the technical obstacles existing in the industry in China No.4 is one of the cases. The technical obstacle is that the structure attached to the spiral drilling rod for a drilling machine could not fulfill the function of cleaning soil well. This results in low efficiency for the drilling process and safety problems. For the past years, there were no engineers to identify this obstacle as a technical problem to be solved in the industry for drilling machine development in China. This time, the engineer from a company located in Xinhe, Hebei province, finds the problem and solves it as an operating contradiction. The incremental innovation has emerged in the market of China.

To identify a technical obstacle in an industry and find its solutions may result in new products in this industry. This is a kind of opportunity for companies.

Opportunity 4: development of a new product from elimination of the technical obstacles existing in a company No.7 is the case. The products of the company are engineering plastics. The processes being used now in the company need a lot of water to eliminate the impurities of the products. The water should be heated and the energy is consumed in the manufacturing process. The treatment of used water also consumes energy. The situation has not changed in the company for years. The engineer in our class from that company finds that the situation should be changed. After abstraction and transformation, the situation is changed to an operating contradiction. After solving the contradiction, a new process is built and water needed is reduced.

Inside a company, there are also a lot of problems which exist for several years. Everyone does not consider them to be problems that should be solved. If a new point of view is introduced and applied, one may find that something must be changed. The root case may be an operating contradiction, which is an opportunity in a company.

Opportunity 5: development of a new product from elimination of the technical obstacles in the project being carried out No.10 is one case of this kind. A company located in Tianjin produces hydraulic, pneumatic actuators and their electrical control systems. A single order gained in the company is a big actuator for a special application. But the control system for this order produces much heat during the work, and the temperature exceeds the needed value. For some time, the problem was not solved 
in the company. The engineer of our class from that company identifies the technical obstacle and solving as his project. At last, eight operating contradictions are solved, and the temperature of the control system is reduced to a certain acceptable value.

So some root causes hampering an innovative project in a company may be one or more operating contradictions. Solving them is a path to get out of the trouble and an opportunity for the company.

\section{Application of the opportunities}

The opportunities above are from the inventions of the engineers' projects in our classes. In a company, the inventions should be evaluated for possible opportunities. If an opportunity does exist, the implementation to push it into an innovation should be carried out. At this situation, a team is needed. Figure 7 shows the process of applying the opportunities during and after training.

The outputs of a training class are several inventions in the form of patent applications and new processes. An evaluation for the inventions should be made in a company at once in order to implement the following activities for both product or process innovations. The manager in a certain level may identify the value of an invention from the opportunities. If a selected invention is worth to be invested in, the manager should organize a team to push the invention into innovation timely.

\section{Results and discussions}

The analysis of 244 projects in our ten training classes from 2009 to 2012 shows that 164 of the projects are related to operating contradiction solving, which is $67.2 \%$ of the total numbers. The number shows that there are many contradictions in innovation processes in companies of china, which is the answer of Q1. In the companies of developed countries (Imoh et al. 2011), the number is 30 of the 40 respondents who use the tool of contradiction solving. The frequencies applying contradiction-solving method of TRIZ both in the companies of developed countries and in China are similar. We find the truth that innovation type originated from the most engineers or researchers in various workplaces in companies is incremental innovation. To identify and solve operating contradictions in companies are driving forces for the processes of incremental innovations in companies in China.

The starting point for an engineer to push innovation forward in a company is to identify a specific or an original situation that must be changed. The situation is a response to an original problem in the workplace in which the engineer works. The original problem may come from any phase in an innovation process. A dilemma is

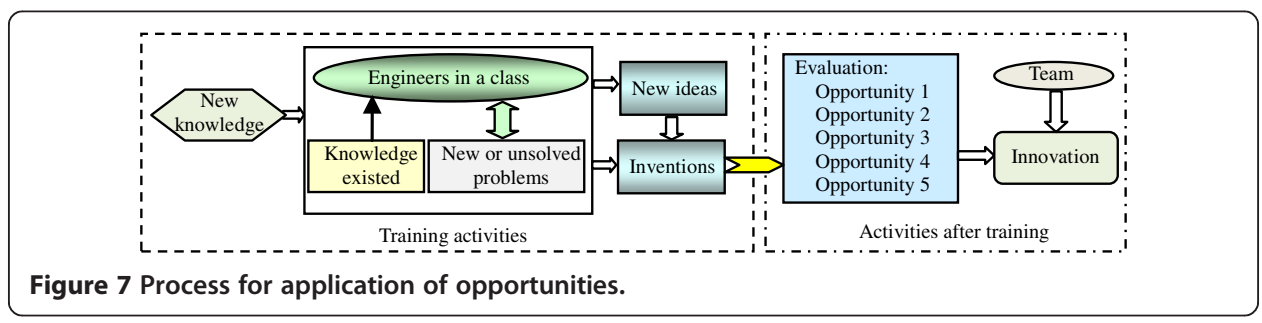


implied in the original situation. The activity of identifying and overcoming the dilemma is the beginning of innovation.

An original situation is identified in a specific phase belonging to an innovation process or main process. There are different innovation processes for various companies in practices. From the case study, we find that there is a pattern from the original situation to solving operating contradictions, which is a process model with six steps. This is an additional process because it is separated from the main process. In this process, the method of contradiction solving in TRIZ is applied. The evaluated solutions of the operating contradictions from the additional process are returned to the phase of the main process. After the application of the solutions, the dilemma is overcome and the activities in main innovation process are ongoing. At the last of the process, an innovation emerges in the company and in the market. This is the answer of the Q2.

After analyzing the project cases, we also find that the engineers' inventions in our classes result in five opportunities for the new product development or following innovations in companies. If one or two opportunities are identified timely in a company, the new products or processes will be developed rapidly. Managers in some level in a company, in which some engineers are joining our training classes, should pay more attention to the training processes. This is the answer of Q3.

In this study, we do not make a detailed analysis for the transformation from an administrative contradiction to some operating contradictions. The transformation in the case (Petrov 2004) is direct. But from the ten projects, we find that the transformation may be a direct or complex process, which is dependent on the situations. A general process model is needed for engineers to make the transformation. This will be the content for future research.

\section{Conclusions}

Of the 244 engineers' projects studied, $67.2 \%$ are related to solving operating contradictions. The percentage shows that there are many operating contradictions in the innovative processes in companies in China. To identify and solve them are forces to push the innovative activities forward.

The simple process for contradiction solving includes abstraction, transformation, and contradiction solving. In detail, the process is a sequential model with six steps, which is an additional process from the main innovation process. The model is not only domain independent but also forms a pattern with application for engineers.

The ten case projects studied do imply five innovative opportunities for companies. If the opportunities are identified and implemented timely in companies, the innovation process will be accelerated.

In the future, we will make a detailed analysis for the transformation from an administrative contradiction to some operating contradictions. More cases from the training classes under way will be collected and analyzed. More discussions with engineers in workplaces are also needed for researchers to find some clues. 
Received: 2 November 2014 Accepted: 3 February 2015

Published online: 04 March 2015

\section{References}

Albers, A, Deigendesch, T, \& Schmalenbach, TH. (2011). TRIZ-box-improving creativity by connecting TRIZ and artifacts. Procedia Engineering, 9, 214-221.

Altshuller, G. (1999). The Innovation Algorithm, TRIZ Systematic Innovation and Technical Creativity. Worcester: Technical Innovation Center Inc.

Baldussu, A, Becattini, N, \& Cascini, G. (2011). Network of contradictions analysis and structured identification of critical control parameters. Procedia Engineering, 9, 3-17.

Belski, I. (2011). TRIZ course enhances thinking and problem solving skills of engineering students. Procedia Engineering, 9, 450-460.

Birdi, K, Leach, D, \& Magadley, W. (2012). Evaluating the impact of TRIZ creativity training: an organizational field study. R\&D Management, 42(4), 315-326.

Cavallucci, D, Rousselot, F, \& Zanni, C. (2010). Initial situation analysis through problem graph. CIRP Journal of Manufacturing Science and Technology, 2(4), 310-317.

Cempel, C. (2013). Application of TRIZ approach to machine vibration condition monitoring problems. Mechanical Systems and Signal Processing, 41(1-2), 328-334.

Cousins, KC, Robey, D, \& Zigurs, L. (2007). Managing strategic contradictions in hybrid teams. European Journal of Information Systems, 16, 460-478.

Harnesk, R, \& Anrahamsson, L. (2007). TQM: an act of balance between contradictions. The TQM Magazine, 19(6), 531-540.

Hernandez, NV, Schmidt, LC, \& Okudan, GE. (2013). Systematic ideation effectiveness study of TRIZ. Transactions of the ASME Journal of Mechanical Design, 135(10), 1-10.

Herstatt, C, \& Kalogerakis, K. (2005). How to use analogies for breakthrough innovations. International Journal of Innovation and Technology Management, 2(3), 331-347.

Houssin, R, \& Coulibaly, A. (2011). An approach to solve contradiction problems for the safety integration in innovative design process. Computers in Industry, 62(4), 398-406.

Hsieh, HT, \& Chen, JL. (2010). Using TRIZ methods in friction stir welding design. The International Journal of Advanced Manufacturing Technology, 46(3), 1085-1102.

Imoh, MI, David, P, \& Robert, P. (2011). A review of TRIZ, and its benefits and challenges in practice. Technovation, 33(2-3), 30-37.

Juppa, ML, Campeana, IF, \& Travcenkoa, J. (2013). Application of TRIZ to develop an in-service diagnostic system for a synchronous belt transmission for automotive application. Procedia CIRP, 11, 114-119.

Karen, G. (2011). TRIZ for Engineers: Enabling Inventive Problem Solving. Chichester: John Wiley \& Sons, Ltd.

Kiatake, M, \& Petreche, J. (2012). A case study on the application of the theory of inventive problem solving in architecture. Architectural Engineering and Design Management, 8(2), 90-102.

Koen, PA, Ajamian, GM, Boyce, S, Clamen, A, Fisher, E, Fountoulakis, S, Johnson, A, Puri, P, \& Seibert, R. (2002). Fuzzy front end: effective methods, tools and techniques. In P Belliveau, A Griffen, \& S Sorer-meyer (Eds.), PDMA Toolbook for New Product Development (pp. 2-35). New York: John Wiley and Sons.

Lee, K. (2013). Effective strategy to introduce and propagate TRIZ into companies based on the bad and good experiences in Korea (pp. 49-657). Paris: TRIZ Future 2013. 29-31 October 2013.

Leon, N, \& Cho, SK. (2009). Computer aided innovation. Computers in Industry, 60(8), 537-538.

$\mathrm{Li}, \mathrm{T}$. (2010). Applying TRIZ and AHP to develop innovative design for automated assembly systems. The International Journal of Advanced Manufacturing Technology, 46(3), 301-313.

Mann, D, Dewulf, S, Alotin, B, Zusman, A, 2003. Matrix 2003: updating the TRIZ contradiction matrix; Clevedon: IFR Press.

Nakagawa, T. (2011). Education and training of creative problem solving thinking with TRIZ/USIT. Procedia Engineering, 9, 582-595.

Pahl, G, \& Beitz, W. (1996). Engineering Design — A Systematic Approach (2nd ed.). London: Springer.

Petrov, V. (2004). Logic of ARIZ (pp. 315-331). Floremce: TRIZ Future Conference 2004. 3-5 November 2004.

Porter, ME. (1990). The competitive advantage of nations. Harvard Business Review, 68(2), 73-91.

Rousselot, F, Cecilia, ZM, \& Cavallucci, D. (2012). Towards a formal definition of contradiction in inventive design. Computers in Industry, 63(3), 231-242.

Russo, D, \& Birolini, V. (2011). Towards the right formulation of a technical problem. Procedia Engineering, 9, 77-91.

Savransky, SD. (2000). Engineering of Creativity. New York: CRC Press.

Savransky, SD 1999. Attributes of the inventive problems. In, AAAI Spring Symposium on Search Techniques for Problem Solving under Uncertainty and Incomplete Information, Stanford University. California: AAAI press.

Schultze, U, \& Stabell, C. (2004). Knowing what you don't know? Discourses and contradictions in knowledge management research. Journal of Management Studies, 4(4), 549-573.

Smith, WK, \& Tushman, ML. (2005). Managing strategic contradictions: a top management model for managing innovation streams. Organization Science, 16(5), 522-536.

Srinivasan, R, \& Krasla, A. (2006). Application of the TRIZ creativity enhancement approach to design of inherently safer chemical processes. Chemical Engineering and Processing, 45(6), 507-514.

Takeuchi, H, Osono, E, \& Shimizu, N. (2008). The contradictions that drive Toyota's success. Harvard Business Review, 86(6), 96-104.

Tan, RH. (2002). Innovative Design - The Theory of Inventive Problem Solving (TRIZ) (in Chinese). Beijing: Mechanical Industry Press.

Tan, RH. (2007). Process of two stages analogy-based design employing TRIZ. International Journal of Product Development, 4(1-2), 109-121.

Tan, RH. (2013). Seven stimuli to identify opportunities of innovation: a practice of training innovative engineers and some findings in China. American Journal of Industrial and Business Management, 3(8), 725-739. 
Tan, RH, \& Zhang, HG. (2014). Interactive training model of TRIZ for mechanical engineers in China. Chinese Journal of Mechanical Engineering, 27(2), 240-248.

Tan, RH, Ma, JH, Liu, F, \& Wei, ZH. (2009). UXDs-driven conceptual design process model for contradiction solving using CAls. Computers in Industry, 60(8), 584-591.

Yeh, CH, Huang, CY, \& Yu, CK. (2011). Integration of four-phase QFD and TRIZ in product R\&D: a notebook case study. Res Eng Design, 22(3), 125-141.

Zhang, Y. (2010). Analysis and evaluation of enterprise innovation ability conversion. International Journal of Innovative Management, Information \& Production, 1(1), 73-81.

Zhao, YJ, \& Zhang, MQ. (2005). China manufacturing industrial competence: evaluation and analysis. Economics Theory and Economical Management, 25(5), 23-30.

\section{Submit your manuscript to a SpringerOpen ${ }^{\circ}$ journal and benefit from:}

- Convenient online submission

- Rigorous peer review

- Immediate publication on acceptance

- Open access: articles freely available online

- High visibility within the field

Retaining the copyright to your article

Submit your next manuscript at $>$ springeropen.com 